\title{
Reply to Chemical Risk Factors of Primary Liver Cancer: A Short Comment [Response To Letter]
}

\author{
Adam Barsouk' \\ Krishna Chaitanya Thandra ${ }^{2}$ \\ Kalyan Saginala ${ }^{3}$ \\ Prashanth Rawla (iD ${ }^{4}$ \\ 'Sidney Kimmel Cancer Center, Jefferson \\ University, Philadelphia, PA, 19107, USA; \\ ${ }^{2}$ Department of Pulmonary and Critical \\ Care Medicine, Sentara Virginia Beach \\ General Hospital, Virginia Beach, VA, \\ USA; ${ }^{3}$ Plains Regional Medical Group \\ Internal Medicine, Clovis, NM, 88I0I, \\ USA; ${ }^{4}$ Department of Medicine, Sovah \\ Health, Martinsville, VA, 24II2, USA
}

\section{Dear editor}

We would like to thank Dr. Laraib Ghanghro for his insightful feedback and for bringing these compounds and their metabolites to our attention. Our understanding of HCC pathogenesis is always changing and contributions like his are essential to keeping physicians, researchers and public health officials informed.

\section{Disclosure}

All the authors declare no conflict of interest in this communication. 
Dove Medical Press encourages responsible, free and frank academic debate. The content of the Hepatic Medicine: Evidence and Research 'letters to the editor' section does not necessarily represent the views of Dove Medical Press, its officers, agents, employees, related entities or the Hepatic Medicine: Evidence and Research editors. While all reasonable steps have been taken to confirm the content of each letter, Dove Medical Press accepts no liability in respect of the content of any letter, nor is it responsible for the content and accuracy of any letter to the editor.

Hepatic Medicine: Evidence and Research

Dovepress

\section{Publish your work in this journal}

Hepatic Medicine: Evidence and Research is an international, peerreviewed, open access journal covering all aspects of adult and pediatric hepatology in the clinic and laboratory including the following topics: Pathology, pathophysiology of hepatic disease; Investigation and treatment of hepatic disease; Pharmacology of drugs used for the

treatment of hepatic disease. Issues of patient safety and quality of care will also be considered. The manuscript management system is completely online and includes a very quick and fair peer-review system, which is all easy to use. Visit http://www.dovepress.com testimonials.php to read real quotes from published authors. 